РОЗРОБКА НАВЧАЛЬНОЇ ПРОГРАМИ «ХОРЕОГРАФІЯ В СЕРЦІ» ІЗ ЗАСТОСУВАННЯМ ІНФОРМАЦІЙНО-КОМУНІКАЦІЙНИХ ТЕХНОЛОГІЙ У ПРОЦЕСІ ПІДГОТОВКИ МАЙБУТНІХ ВИКЛАДАЧІВ ХОРЕОГРАФІЇ

\title{
DEVELOPMENT OF THE EDUCATIONAL PROGRAM "HOREOGRAPHY IN HEART" WITH THE USE OF INFORMATION AND COMMUNICATION TECHNOLOGIES IN THE PROCESS OF PREPARATION OF FUTURE CHOREOGRAPHY TEACHERS
}

УДК 37.037

DOI https://doi.org/10.32843/2663-60852019-14-1-9

Добролюбова Н.В., старший викладач кафедри народної хореографії Комунального закладу «Харківський вищий коледж мистецтв»
У статті розглядається використання сучасних інформаційно-комунікаційних технологій в освітньому процесі підготовки майбутніх викладачів хореографрії, які є реалією сучасної освіти в Україні. Обгрунтовано необхідність посилення аудиторної орорми проведення занять із хореограсрії для студентів закладів вищої освіти, позааудиторних форм, зокрема, заснованих на самостійному виконанні хореографрічних вправ. Обгрунтовано організацію експериментальної роботи з упровадження навчальної програми домашніх завдань «Хореограсрія в серці» за розділом «Народна хореографрія», для студентів 1-2-х курсів, заснованої на методиці навчання з використанням інформачійно-комунікаційних технологій. Узагальнено результати експериментальної перевірки ефективності навчальної програми «Хореограсрія в серці». Застосування інформаційних технологій навчання дозволяє реалізувати вимоги теоретичного і методичного розділів навчальних програм із хореограopii.. Розроблення і впровадження електронних засобів сприяють підвищенню рівня інобормачійної культури студентів завдяки поданню інформації в мультимедійній фрормі, збільшують ефективність сприйняття навчального матеріалу, пов'язаного з руховою діяльністю. Отже, інфрормаційні технології навчання дозволяють студентам ефективно освоювати теоретичний і методичний розділи програми. У процесі дослідження встановлено, що використання інтернет-блогів для виконання домашніх завдань $є$ невід'ємною частиною повноцінного засвоєння навчального матеріалу та забезпечення успішності навчання майбутніх викладачів хореографbiі. Для поліпшення успішності розроблено та впроваджено в освітній процес програму домашніх завдань із постановки і композиції танцю «Хореографрія в серцір, засновану на використанні інфрормаційно-комунікаційних технологій.

Ключові слова: домашні завдання, інсрормаційно-комунікаційні технології, методика, програма, студенти, хореографрія.
The article considers the use of modern information and communication technologies in the educational process of future choreography teachers' training, which is the realization of modern education in Ukraine. Substantiated the need to strengthen the classroom form of choreography classes for students of higher educational institutions, extracurricular forms, in particular, based on independent performance of choreographic exercises. The justified organization of experimental work on the implementation of the homework curriculum "Choreography in the heart" under the section "Folk choreography" for students of 1-2 courses based on the method of teaching using information and communication technologies. The results of experimental verification of the effectiveness of the choreography in the heart curriculum are summarized. The use of information technology training allows you to implement the requirements of the theoretical and methodological sections of curriculum for choreography. The development and introduction of electronic means help to increase the level of information culture of students by presenting information through multimedia forms, which increase the efficiency of perception of educational material related to motor activity. Thus, information technology training allows students to effectively master the theoretical and methodological sections of the program. So, in the course of the research, it was established that the use of Internet blogs for homework is an integral part of the full-fledged mastering of educational material and the success of training future teachers of choreography. To improve performance, a homework program for the performance and composition of the dance "Choreography in the Heart", based on the use of information and communication technologies, was developed and introduced into the educational process. Key words: homework, information and communication technologies, methodology, program, students, choreography.
Постановка проблеми в загальному вигляді. Сьогодні питання якості підготовки висококваліорікованих фрахівців із хореограсрії та підвищення рівня їхніх умінь і навичок у професійній діяльності надзвичайно актуальне. Тому перед системою вищої освіти постало найважливіше завдання формування інорормаційної культури майбутнього викладача хореографрії у процесі профресійного розвитку в умовах інформаційно-освітнього простору. Важливість фрормування інформаційної культури в майбутнього викладача хореографрії полягає в тому, що вона необхідна для майбутньої профресійної діяльності, а також для успішного входження у профресію в закладі освіти. Виходячи із цього, її формування підвищує конкурентоспроможність майбутнього викладача хореографрії на європейському і світовому ринках праці.

Незважаючи на значущість даного питання, виявлено низку чинників, які ускладнюють організацію навчальних занять, готовності майбутніх викладачів хореографії до застосування цих технологій у професійній діяльності, серед них такі: недостатня мотивація студентів до їх виконання, складність перевірки постановок і комбінацій. Крім того, проблемним і актуальним залишається питання щодо виконання домашнього завдання 3 
хореографії, розроблення технологій, які б найефективніше сприяли залученню студентів до регульованої хореографрічної діяльності.

Інформаційно-комунікативні технології в освіті сьогодні посідають одне із провідних місць, проте проблематика використання їх у студентів потребує детального вивчення.

Аналіз останніх досліджень і публікацій. Процес модернізації профресійної підготовки орахівців із хореографії вписується в загальну стратегію освітньої політики України, одним 3 основних завдань якої $€$ досягнення сучасної якості освіти в умовах інфрормаційно-освітнього простору, його відповідність актуальним і перспективним потребам профресійного розвитку особистості, суспільства і держави відповідно до європейських і світових стандартів вищої освіти.

Зараз є необхідність у спеціальному вивченні проблеми професійної підготовки майбутнього викладача хореографії в контексті організації готовності до застосування інфрормаційно-комунікаційних технологій у професійній діяльності в умовах інфрорматизації освіти. Мета професійної підготовки майбутнього викладача хореографії у процесі навчання визначається соціальним замовленням держави й інфрормаційним суспільством, полягає в підвищенні рівня його профресійної готовності до застосування інформаційних технологій у просресійній діяльності [1].

Протягом багатьох років фрахівці різних наук досліджують проблеми розвитку інфрорматизації вищої освіти в Україні. Проте вивченню проблем інорорматизації професійної підготовки майбутнього викладача хореограсрії не приділяється достатньо уваги. Активна роль застосування інорормаційних технологій у вищій освіті в Україні зумовлена тим, що комп'ютерні засоби навчання забезпечують нові можливості для майбутнього викладача хореографії, а також дозволяють реалізувати сучасні педагогічні інноваційні й акмеологічні технології навчання на більш високому науково-методичному рівні.

Ресрормування сучасної вищої освіти відбувається в умовах широкомасштабного впровадження інфрормаційних технологій в усі галузі знань. Тому одним із головних завдань вищої освіти $€$ навчання майбутніх викладачів хореографої користуватися інформаційними технологіями в освітньому процесі та у професійній діяльності.

Застосування інфрормаційних технологій:

- здійснюється як в освітньому процесі, де готуються фрахівці 3 хореографії, так і у професійній діяльності, де потрібні спеціальні знання, уміння і навички: аналіз техніки танцювального руху, створення постановчих схем, адаптаційні моделі до хореографрічної майстерності [2];

- сприяє не тільки його індивідуалізації та креативності, а й розвитку інтелектуальних здібностей, надає можливість самостійно й ефективно працювати в мережі Інтернет.

Зараз спостерігається поширення використання Інтернету, інтеграції національних систем вищої освіти в міжнародному інорормаційно-освітньому просторі. Для ефективної професійної діяльності майбутнього викладача хореографії, який працюватиме в інфрормаційному суспільстві, необхідно не тільки вдало використовувати інорормаційно-комунікаційні технології в майбутній професійній діяльності, але й навчитися раціонально використовувати професійну інформацію для розвитку профресійно-креативного мислення під час навчання в закладі освіти [3].

На наш погляд, саме вирішенню основних із цих проблем сприятиме обґрунтування програми навчання студентів закладів вищої освіти з використанням інорормаційно-комунікаційних технологій.

Мета статті - розкрити можливості застосування інформаційно-комунікаційних технологій у період професійної підготовки майбутніх викладачів хореографрії.

Виклад основного матеріалу. Використання сучасних інфрормаційно-комунікаційних технологій в освітньому процесі підготовки майбутніх викладачів хореографрії $€$ реалією сучасної освіти в Україні. Інформаційно-комунікаційні технології виступають умовою перенесення уваги студентів із хореографрічної активності на інтелектуальну. Виходячи із цього, продуманість методики застосування інформаційних технологій не тільки не спотворює традиційне уявлення про заняття 3 хореограсрії, а й робить його сучасним. Підвищується есрективність виконання хореограсрічних вправ, постановчих дій і навчальних завдань, удосконалюються навички й уміння постановки композицій тощо.

Об'єктивно наявна недостатність розроблення методичного забезпечення освітнього процесу для підготовки викладачів хореографрії із застосуванням інорормаційно-комунікаційних технологій визначила мету дослідження - обґрунтувати необхідність посилення аудиторної форми проведення занять із хореографії для студентів, позааудиторних фрорм, зокрема заснованих на самостійному виконанні хореографічних вправ; описати організацію експериментальної роботи з упровадження навчальної програми домашніх завдань «Хореографрія в серці» за розділом «Народна хореографрія» для студентів 1-2-х курсів, заснованої на інфрормаційно-комунікаційних технологіях, узагальнити результати експериментальної перевірки.

Аналізуючи специфічні особливості викладання хореографії в розвинених європейських країнах, ми зазначили різницю в постановці мети естетичного виховання. Виходячи 3 мети викладання дисципліни «Композиція та постановка танцю», 
навчальна програма дисципліни в Європі насичена теоретичним - лекційним матеріалом, який читають студентам професори спеціалізованих ЗВО із психології, вікової фрізіології, фрахівці з різних видів танцю, а також судді, журналісти, менеджери. Матеріал лекцій закріплюється на семінарських групових заняттях. Заняття ж практичні здебільшого проходять у самостійному режимі, 3 використанням і застосуванням отриманих знань на лекціях і семінарах. Освітній вектор спрямовано не на розвиток основних якостей студента, а на навчання його вмінню організовувати, створювати творчу атмосореру у професійній діяльності та в особистому житті.

Усвідомлення мети і завдань, що стоять перед сучасним випускником у галузі хореографії, привело нас до необхідності кардинальних змін структурно-логічної схеми викладання дисципліни «Композиція та постановка танцю» у бік збільшення обсягу лекційних годин і пропорційного введення семінарських занять. Сучасна інтелігентна, освічена людина зобов'язана не лише бути організатором творчого клімату у своєму профресійному середовищі (виконуючи соціально орієнтовану функцію керівника), але й активно слідувати доцільності розвитку своєї особистості (виконуючи особистісно орієнтовану функцію).

Критеріями оцінювання 3 дисципліни «Композиція та постановка танцю» майбутніх фрахівців із хореографрії повинні стати: рівень творчих здібностей, гармонійний розвиток i, головним чином, хореографрічні знання, уміння та навички.

Керуючись вищезазначеною концепцією викладання дисципліни «Композиція та постановка танцю», усвідомлюючи, що дієвість будь-якого управлінського процесу, як відомо, залежить не лише від використовуваних засобів, але й багато в чому від методичних особливостей їх застосування, ми розробили методичне забезпечення практичних занять, а саме інноваційне активне навчання.

Істотну допомогу майбутнім викладачам хореографрії можуть надати методи активного навчання, які порівняно із традиційними мають низку переваг:

1) навчання відбувається в умовах, максимально наближених до реальної практичної діяльності студентів;

2) методи активного навчання засновані на колективному виробленні рішень;

3) методи активного навчання дозволяють спеціальними засобами створити так звану керовану емоційну напругу студентів, тобто ігри відбуваються в атмосорері емоційного підйому.

Отже, використання активних методів навчання передбачає підвищення інтенсивності процесу навчання. Такі методи не лише є чинником психологічної розрядки, але й можуть бути використані як засіб для вирішення практичних завдань навчання. У процесі занять із хореографрії доцільно використовувати методи активного навчання: метод аналізу конкретних ситуацій; імітаційні ігри.

Метод аналізу конкретних ситуацій. У разі використання методу аналізу конкретних ситуацій студентам пропонується ситуація, пов'язана 3 якимось моментом фрункціонування конкретної системи, ставиться завдання ухвалити управлінське рішення у вказаній ситуації. Для активізації заняття можуть створюватися декілька груп, що змагаються, кожна $з$ яких виробляє власний варіант рішення. Характерні ознаки методу аналізу конкретних ситуацій:

1) наявність моделі керованої системи;

2) відсутність індивідуальних ролей керівників, наявність лише однієї колективної ролі;

3) багатоваріантність рішень;

4) єдина мета під час вироблення рішення (усій групі пропонується одна ситуація, щодо якої і належить ухвалити рішення);

5) наявність системи групової оцінки діяльності студентів.

Використання в освітньому процесі методу аналізу конкретних ситуацій дозволяє фрормувати у студентів уміння і навички вирішення професійних завдань.

Імітаційні ігри. Одним із найбільш значущих інноваційних методів активного навчання $€$ імітаційні ігри, де поєднуються характерні ознаки методу аналізу конкретних ситуацій. Це робить ïх найбільш ефективним методом активного навчання, але і найбільш трудомістким щодо розроблення. Для її розігрування потрібні ролі. Отже, перше, що виділяє імітаційну гру з інших методів активного навчання, це те, що ії основою може бути лише цілісна модель системи, а не окремі її елементи. Друга принципова відмінність полягає в тому, що в імітаційній грі динамічність модельованої системи виявляється в наявності «ланцюжка рішень». Рішення, що ухвалюється учасниками гри на основі початкової інсрормації, впливає на модель об'єкта управління, змінюючи його початковий стан. Відомості про ці зміни через систему оцінювання діяльності учасників поступають в ігровий комплекс.

Однією $з$ найважливіших ознак, що характеризують імітаційну гру, є колективне вироблення рішення. Колективність рішень в імітаційних іграх відбивається в передбаченій структурі гри. Захист власних рішень, критика рішень інших учасників, обов'язкове обговорення висловлених критичних зауважень дозволяють підійти до раціонального (оптимальне) рішення і сорормувати підходи ігрової групи на подальших етапах вироблення й обговорення рішень.

Також аналіз літературних джерел показав, що сьогодні недостатньо уваги приділяється використанню новітніх форм для розвитку й 
удосконалення вмінь і творчих якостей студентів. Саме тому вважаємо за потрібне розробити й упровадити в освітній процес навчальну програму домашніх завдань із хореограсрії для студентів 1-2-х курсів. Програма домашніх завдань може бути використана як допоміжний засіб, що буде сприяти кращому вивченню матеріалу заняття, а також фрормуванню інтересу до навчання, підвищенню пізнавальної активності студентів, цілісному сприйманню інформації як системи з фрормування розумових якостей, рухових умінь та навичок, успішності студентів, їхньому гармонійному розвитку загалом.

Для проведення експериментальної роботи нами виділено основні етапи: констатувальний, пошуковий і формувальний.

На першому констатувальному етапі вивчалися особливості виконання домашніх завдань із хореографрії із застосуванням інформаційно-комунікаційних технологій; розглядалися особливості проведення занять із хореографрічної постановки танцю; аналізувалася нормативна база щодо критеріїв оцінювання рівня творчих здібностей студентів; вивчалися особливості музично-ритмічних занять зі студентами, досліджувалися особливості застосування інформаційно-комунікаційних технологій у процесі професійної діяльності та специфріка використання їх у системі домашніх завдань. На цьому ж етапі проводилися опитування студентів 1-2-х курсів та викладачів хореографрічного мистецтва щодо значення домашніх завдань; вивчалася науково-методична література з теорії та методики мистецтва. Констатовано недостатність досвіду використання інформаційно-комунікаційних технологій у домашніх завданнях стандартизованість засобів хореографічного мистецтва у процесі виконання домашніх завдань студентами.

На другому пошуковому етапі на основі висновків і узагальнень, зроблених після теоретичного аналізу проблеми, сорормульовано гіпотезу дослідження, яка лежить в основі експериментальної програми. Формулюючи гіпотезу дослідження, ми виходили із припущення, що за наявності теоретично обґрунтованої навчальної програми домашніх завдань із хореографії для студентів 1-2-х курсів, заснованої на використанні інорормаційно-комунікаційних технологій, спостерігатиметься покращення їхнього рівня професійної підготовленості, музично-ритмічної грамотності, отже, підвищення успішності.

Зважаючи на проблеми дослідження, на цьому етапі розв'язувалися такі завдання:

- теоретично обґрунтувати навчальну програму домашніх завдань «Хореографрія в серці» за розділом «Народна хореографрія», для студентів 1-2-х курсів, на основі інформаційно-комунікаційних технологій;
- розробити критерії оцінювання виконання студентами домашніх завдань.

На третьому фрормувальному етапі відбувалося впровадження в освітній процес ЗВО навчальної програми домашніх завдань із використанням інорормаційно-комунікаційних технологій у період вивчення розділу «Народна хореограсрія»; розроблений спеціальний інтернет-блог, у якому студентам запропоновано використання навчальної програми домашніх завдань «Хореографрія в серці»; здійснювалась перевірка ефективності розробленої програми та статистична оцінка отриманих результатів.

У фрормувальному експерименті взяли участь 125 студентів 1-2-х курсів Комунального закладу «Харківський вищий коледж мистецтв» та Комунального закладу «Харківська гуманітарно-педагогічна академія» Харківської обласної ради, серед них: 63 студенти експериментальної та 62 контрольної груп. Розроблено програму домашніх завдань із хореографії «Хореографрія в серці», засновану на використанні інформаційно-комунікаційних технологій.

Програма містить чотири комплекси вправ із хореографії, які студенти повинні виконувати впродовж другого семестру як на заняттях із постановки та композиції танцю, так і вдома. Програма включає відеоматеріали і полягає у виконанні хореографрічних комплексів вправ на 32 рахунки під музику, тривалістю до 10 хвилин. Програма розрахована на впровадження у другому семестрі навчального року (розділ «Народна хореографрія») із 17 по 34 заняття (18 занять). Для здійснення оцінювання студентів розроблено критерії, які передбачають чотири рівні складності: високий, достатній, середній, низький.

Для виявлення ефективності програми систематично проводилася перевірка засвоєння комплексів хореографії. Після серії занять, на яких закріплювалася техніка виконання комплексів, проводилося контрольне оцінювання за розробленими нами критеріями.

Експеримент організовувався за правилом єдиної різниці, що передбачало однакові умови проведення занять на кожному курсі. 3 тією різницею, що контрольна група не отримувала завдань додому, а виконувала ідентичні з експериментальною групою комплекси на заняттях. Експериментальна група виконувала хореографічні комплекси на заняттях і вдома. Для отримання початкових даних про виконання студентами домашніх завдань ми провели анкетування, у якому взяли участь експериментальна і контрольна групи.

Для виявлення потреби студентів у руховій активності та бажання займатися постановкою танцю ми провели анкетування, за результатами якого виявили, що в середньому $87 \%$ студентів позитивно ставляться до занять, мають бажання 
займатися хореографрічними вправами, розуміють значущість домашніх завдань із хореографії. Проте 100\% студентів обох груп зазначили, що домашні завдання 3 хореографрії вони не виконують, оскільки їх не перевіряє викладач. Опитування викладачів із хореографрії виявило, що їм складно перевіряти домашні завдання і визначати їх для студентів різних рівнів підготовленості. Викладачі також розуміють значущість домашніх завдань, проте задають їх студентам не кожного заняття.

Після впровадження програми домашніх завдань ми вдруге провели анкетування зі студентами експериментальної групи, які мали можливість використати інтернет-блог із навчальною програмою «Хореографрія в серці». За результатами анкетування ми виявили, що запропоновані вправи студентам подобаються, вони значно покращили ставлення до занять і мають бажання надалі виконувати схожі комплекси. Із цього розуміємо, що успішність навчання підвищилася (рис. 1). У контрольній групі вона залишилася на попередньому рівні.

Ефективність програми домашніх завдань «Хореографія в серці» ми виявили завдяки кількісним змінам в успішності студентів. За нашою гіпотезою, успішність навчання в експериментальній групі має підвищитися.

Після впровадження навчальної програми «Хореограсрія в серці» в освітній процес із професійної підготовки майбутніх викладачів хореографії ми опрацювали результати кількісного оцінювання викладачами виконання 4-х хореографрічних комплексів і узагальнили отримані дані. Вони виявилися такими: у контрольній групі якісний показник становив 22,5\%, а в експериментальній - 35,7\%, що на 13,2\% більше, це підтверджує нашу гіпотезу.

Висновки. Застосування інформаційних технологій навчання дозволяє реалізувати вимоги теоретичного та методичного розділів навчальних програм із хореографрії. Розроблення і впровадження електронних засобів сприяють підвищенню рівня інорормаційної культури студентів завдяки представленню інорормації в мультимедійній фрормі, що збільшує ефективність сприйняття навчального матеріалу, пов'язаного з руховою діяльністю. Отже, інфрормаційні технології навчання дозволяють студентам ефективно освоювати теоретичний і методичний розділи програми. У процесі дослідження встановлено, що використання інтернет-блогів для виконання домашніх завдань $€$ невід'ємною частиною повноцінного засвоєння навчального матеріалу та забезпечення успіш-

ності навчання майбутніх викладачів хореографії. Заняття в домашніх умовах не лише покращують творчі здібності, а й задовольняють потребу в русі, виховують позитивне ставлення до систематичних занять. Проте, незважаючи на їхню користь, викладачі хореографрії задають їх не завжди, оскільки стикаються 3 низкою труднощів, серед яких такі: складність перевірки виконання, недостатньо повна інфрормація про виконання практичних завдань. Для покращення успішності навчання розроблено й упроваджено в освітній процес програму домашніх завдань із постановки та композиції танцю «Хореографрія в серці», засновану на використанні інформаційно-комунікаційних технологій. Після перевірки еорективності програми «Хореографрія в серці» ми виявили позитивні результати.

У подальшому дослідженні може бути запропоновано безліч різних варіантів проведення семінарських і практичних занять. Проте в будь-якому разі всі вони мають бути орієнтовані на підвищення активності студентів, отже, проводитися 3 використанням активних методів навчання. Перспектива покращення якості підготовки залежить від використання науково обґрунтованої методики навчання студентів постановки та композиції танцю.

\section{БІБЛІОГРАФІЧНИЙ СПИСОК:}

1. Василина М., Майборода В. Актуальні проблеми практичної підготовки студентів вищої школи України. Проблеми підготовки сучасного вчителя. 2010. № 2. С. 233-237.

2. Інтерактивні технології навчання: теорія, практика, досвід : методичний посібник / авт.-уклад.: О. Пометун, Л. Пироженко. Київ : А.П.Н., 2002. 136 с.

3. Борисова Ю., Власюк О. Комп'ютерні технології як педагогічні інновації у фрізичному вихованні школярів. Педагогіка, психологія та медико-біологічні проблеми фрізичного виховання і спорту. 2013. №. 11. C. 8-13. 